\title{
Foliar spraying with bacterial biocontrol agents for the control of common bacterial blight of bean
}

\author{
Maurício Sangiogo(1), Daniela Pimentel Rodriguez ${ }^{(1)}$, Renata Moccellin ${ }^{(1)}$, \\ Johan Manuel Murcia Bermudez ${ }^{(1)}$, Bianca Obes Corrêa ${ }^{(2)}$ and Andrea Bittencourt Moura ${ }^{(1)}$
}

\begin{abstract}
(1)Universidade Federal de Pelotas, Faculdade de Agronomia Eliseu Maciel, Departamento de Fitossanidade, s/no, Caixa Postal 354, CEP 96010-900 Pelotas, RS, Brazil. E-mail: ms_sangiogo@hotmail.com, danip.rodriguez@hotmail.com, renata.moccellin@gmail.com, jmmurciab@unal.edu.co, andreabittencourtmoura@hotmail.com (2)Universidade Anhanguera Uniderp, Programa de Pós-graduação em Produção e Gestão Agroindustrial, Rua Alexandre Herculano, oo 1400, Jardim Veraneio, CEP 79037-280 Campo Grande, MS, Brazil. E-mail: bianca.obescorrea@yahoo.com.br
\end{abstract}

\begin{abstract}
The objective of this work was to evaluate the effect of foliar spraying with bacterial biocontrol agents (BBAs) on the control of common bacterial blight (CBB) of bean, and on the induction of systemic resistance in bean plants. CBB control by BBAs was evaluated by spraying bean leaves 48 and 24 hours before and after pathogen inoculation (BPI and API, respectively), with: DFs93, Bacillus cereus; DFs513, Pseudomonas veronii; DFs769, B. cereus; the C01 combination, DFs93 + DFs769 + DFs831 (Pseudomonas fluorescens); the C03 combination, DFs348 (Bacillus sp.) + DFs769 + DFs831; and water (control). Systemic effects were analyzed after spraying DFs513, DFs769, C03, and water 72 and 48 hours BPI. Phaseolin production induced by DFs348, DFs513, DFs769, DFs831, and water was also assessed. DFs513, DFs769, and $\mathrm{C} 03$ significantly reduced disease incidence (area under disease progress curve), regardless of spraying time and disease severity when sprayed 72 and 48 hours BPI. The DFs 769 and DFs 831 isolates induced the accumulation of phytoalexin (phaseolin). Therefore, DFs513, DFs769, and C03 show potential for the biocontrol of CBB when applied preventively on bean leaves, besides inducing systemic resistance.

Index terms: Phaseolus vulgaris, Xanthomonas axonopodis pv. phaseoli, biological control, induced systemic resistance (ISR), methods of application, phylloplane.

\section{Pulverização foliar com agentes bacterianos de biocontrole para controle do crestamento bacteriano comum do feijoeiro}

Resumo - O objetivo deste trabalho foi avaliar o efeito da pulverização foliar de agentes bacterianos de biocontrole (ABB) no controle do crestamento bacteriano comum do feijoeiro (CBC) e na indução de resistência sistêmica em plantas de feijão. $\mathrm{O}$ controle do $\mathrm{CBC}$ por $\mathrm{ABB}$ foi avaliado por meio da pulverização, em folhas de feijoeiro, 48 e 24 horas antes e depois da inoculação do patógeno (AIP e DIP, respectivamente), de: DFs93, Bacillus cereus; DFs513, Pseudomonas veronii; DFs769, B. cereus; combinação C01, DFs93 + DFs769 + DFs831 (Pseudomonas fluorescens); combinação C03, DFs348 (Bacillus sp.) + DFs769 + DFs831; e água destilada (testemunha). Os efeitos sistêmicos foram analisados após pulverização de DFs513, DFs769, C03 e água 48 e 72 horas AIP. Também foi avaliada a produção de faseolina induzida por DFs348, DFs513, DFs769, DFs831 e água. DFs513, DFs769 e C03 reduziram significativamente a incidência da doença (área abaixo da curva de progresso da doença), independentemente do momento da aplicação e da severidade da doença quando pulverizados 48 e 72 horas AIP. Os isolados DFs769 e DFs831 induziram o acúmulo de fitoalexina (faseolina). Portanto, DFs513, DFs769 e C03 apresentam potencial para o biocontrole do CBC quando pulverizados preventivamente em folhas de feijão, além de atuarem como indutores de resistência.

Termos para indexação: Phaseolus vulgaris, Xanthomonas axonopodis pv. phaseoli, controle biológico, resistência sistêmica induzida (ISR), métodos de aplicação, filoplano.

\section{Introduction}

Common bacterial blight, caused by Xanthomonas axonopodis pv. phaseoli (Smith) (Xap), is considered one of the most important diseases of the common bean (Phaseolus vulgaris L.) crop and the main one among the bacterial group (Bianchini et al., 2005). In Brazil, there are no estimates on the caused losses; however, damage between 22 and $36 \%$ has been reported in Canada (Gillard et al., 2009; Boersma et al., 2015). The control of common bacterial blight is based on preventive measures (Moura et al., 2009) 
since chemical control has low efficiency (Bianchini et al., 2005) and most Brazilian commercial cultivars are susceptible to the disease. Therefore, it is necessary to search for alternative and efficient control methods with lower environmental impact, among which stand out biocontrol agents. Several authors have reported the biological control of bacterial diseases caused by Xanthomonas spp. (Naue et al., 2014; Halfeld-Vieira et al., 2015; Singh \& Siddiqui, 2015), including the selection of biocontroller bacteria against Xap (Zanatta et al., 2007; Silva et al., 2009).

Biological control involves different action mechanisms, such as antibiosis, parasitism, competition, and induction of resistance (Jamalizadeh et al., 2011). Bacterial biocontrol agents, particularly Bacillus and Pseudomonas, are known for their efficiency and diversity in producing antibiotics responsible for the effective control of various diseases (Khabbaz et al., 2015); these two genera also harbor systemic resistance-inducing species (Akram et al., 2015; Planchamp et al., 2015). The diverse modes of action of the bacterial biocontrol agents attract attention to their preventive and curative uses, inducing resistance and acting by antibiosis, respectively.

Another strategy for improving biocontrol performance is combining the use of microorganisms. The advantage is the cumulative effect of biocontrol mechanisms, antagonizing the pathogen with different modes of action. Better results are expected when biocontrol agents are combined, since this may broaden the spectrum of action against different pathogens and in distinct cultivars of the same host, increasing their biocontrol effect (Jacobsen et al., 2004).

In most studies on biocontrol, the bacterial biocontrol agents are delivered in plants via the microbiolization of seeds (Corrêa et al., 2014; Figueredo et al., 2014; Planchamp et al., 2015); however, leaf spraying has been seldom used for this purpose. The foliar application of bacterial biocontrol agents could improve the control of common bacterial blight of bean. This is the prospect of some bacterial biocontrol agents that control Xap, selected for the treatment of bean seeds (Zanatta et al., 2007), which could increase the levels of compounds related to resistance (Silva et al., 2009), showing broadspectrum effects (Corrêa et al., 2014). However, there is no information available about the behavior of these bacteria when used in foliar spraying.
The objective of this work was to evaluate the effect of foliar spraying with bacterial biocontrol agents (BBAs) on the control of common bacterial blight (CBB) of bean, and on the induction of systemic resistance in bean plants.

\section{Materials and Methods}

Three experiments were conducted to evaluate the control of $\mathrm{CBB}$ of bean by BBAs, applied on common bean (Phaseolus vulgaris L.) plants of the BRS Valente cultivar. The first was used to assess the effect of spraying BBAs on leaves at different times, before and after Xap inoculation, on the control of $\mathrm{CBB}$; the second, the induction of systemic effects; and the third, the induction of phaseolin production. The first and second experiments were performed twice. A completely randomized design was used for all experiments, besides a factorial arrangement for the first and second ones (BBAs $\times$ time of pathogen inoculation), with six replicates in the first experiment, seven in the second, and four in the third.

The used BBA isolates are from the collection of the plant bacteriology laboratory of Universidade Federal de Pelotas, selected to control CBB through seed treatment (Zanatta et al., 2007; Corrêa et al., 2014).

For all assays, two plants were grown per pot in 2-kg unsterilized commercial substrate. The plants were kept in a greenhouse with partially controlled temperature and micro-sprinkler irrigation.

The treatments consisted of foliar spraying of the following BBAs, either individually or in combinations: DFs93, Bacillus cereus; DFs513, Pseudomonas veronii; DFs769, B. cereus; C01, DFs93 + DFs769 + DFs831 (Pseudomonas fluorescens); C03, DFs348 (Bacillus sp.) + DFs769 + DFs831; besides sterile water, as the control. The $\mathrm{C} 01$ and $\mathrm{C} 03$ combinations were recommended by Corrêa et al. (2014) for the control of several bean diseases via seed treatments.

In the first experiment, the assays were conducted in two steps: the first with all treatments; and the second with the most efficient ones, i.e., DFs513, DFs769, and C03. After the complete expansion of the third trefoils, the BBA suspensions were sprayed at different times relative to pathogen (Xap) inoculation: first application, at 24 and 48 hours before inoculation (BPI) and at 24 and 48 hours after inoculation (API); 
and repeat application, at 72 and 48 hours BPI and at 48 hours API.

In the second experiment, to check the occurrence of induced systemic effects, the most efficient BBAs - DFs513, DFs769, and C03 - were sprayed on trefoils without pathogen inoculation, according to HalfeldVieira et al. (2006), at 72 and 48 hours BPI. To prevent the drift of BBA spray, the trefoil where Xap would be inoculated was covered with aluminum foil during application.

In the third experiment, to verify phaseolin production, the BBAs of the most efficient treatments, i.e., DFs513, DFs769, DFs348 isolates, DFs831, and $\mathrm{C} 03$, were evaluated using the method proposed by Dixon et al. (1983) and adapted by Brand et al. (2010). Bean seeds were disinfected in $1 \%$ sodium hypochlorite for $5 \mathrm{~min}$ and washed in sterile distilled water. Then, the seedlings were planted in sterile sand and conditioned in a growth chamber at $25^{\circ} \mathrm{C}$ in the dark. After seven days, 5-cm hypocotyl segments were cut, washed in sterile water, and dried on sterile filter paper. Four hypocotyl segments were placed in a Petri dish containing filter paper moistened with sterile distilled water. The hypocotyls were sprayed with BBA suspension, and a $0.85 \%$ saline solution was used as the control. The Petri dishes were then kept at $25^{\circ} \mathrm{C}$, in the dark, for 48 hours. Afterwards, the hypocotyls were transferred to tubes containing $10 \mathrm{~mL}$ ethanol, at $4^{\circ} \mathrm{C}$, for 48 hours; the tubes were shaken for 1 hour to extract phaseolin, measured indirectly by absorbance at $280-\mathrm{nm}$ wavelength in a spectrophotometer. The results were expressed as absorbance units per gram of fresh weight $\left(\mathrm{ABS} \mathrm{g}^{-1} \mathrm{fw}\right)$.

The BBAs and Xap were grown in 523 medium (Kado \& Heskett, 1970) at $28^{\circ} \mathrm{C}$ for 24 hours. Suspensions were prepared by adjusting the concentrations to $\mathrm{A}_{540}=0.4$ for BBAs and $\mathrm{A}_{540}=0.2$ for Xap. The BBA combinations were prepared missing equal volumes of the suspension of each BBA prepared individually.

The used pathogenic isolate, Xap28, was obtained from a leaf with typical symptoms of CBB. The pathogen was inoculated in the third fully-expanded trifoliate leaf of the bean plants by the "cutting with scissors method" (ten cuts per leaf), as described by Alfenas \& Mafia (2007). The plants were kept in a humid chamber for 24 hours after inoculation.

After the onset of symptoms, incidence and severity were assessed five times at two-day intervals. For incidence, the number of cuts in the leaves showing typical symptoms of CBB was taken into account. The severity of each cut was classified according to the scale proposed by Rava (1984). The area under the incidence progress curve (AUIPC) and the area under the severity progress curve (AUSPC) of the disease were calculated (Campbell \& Madden, 1990).

Incidence data were subjected to the Box-Cox transformation for further analysis, and all data were subjected to the analysis of variance. Means were compared by Duncan's test, at 5\% probability, using the R software (R Core Team, 2015).

\section{Results and Discussion}

BBAs significantly affected the severity of CBB symptoms, but not the incidence of the disease. For initial incidence, no interaction was observed between factors, resulting in an initial reduction only in the second spraying time (Figure 1). In addition, the cumulative effect (AUIPC) followed the same pattern, also differing only in the repeat application, when the treatments C03, DFs769, and DFs513 reduced the AUIPC by $32,30.8$, and $21.5 \%$, respectively. BBA spraying 72 hours BPI resulted in the lowest AUIPC, i.e., in a decrease of $19.8 \%$ in relation to 48 hours API, which did not differ from 48 hours BPI.

The effect on symptom severity varied depending on the time of BBA spraying, with a significant interaction in both application times. In the first spraying time (Table 1), there was a reduction in the AUSPC when three of the treatments were applied preventively 48 hours BPI and one in a curative mode 48 hours API. In the repeat spraying, when the number of treatments was reduced and a longer interval was included between BBA spraying and the challenge with Xap, only the results for 48 hours BPI were repeated; it should be noted that increasing the application interval did not result in greater control and also reduced the number of effective treatments.

In general, BBA foliar spraying applied preventively provided CBB control. However, DFs513, DFs769, and $\mathrm{C} 03$ were the only treatments with stable effect, significantly reducing the incidence and severity of the disease in most trials.

The two BBA combinations tested consisted of a mixture of bacteria of the genus Bacillus and Pseudomonas; however, only C03 stood out among the 

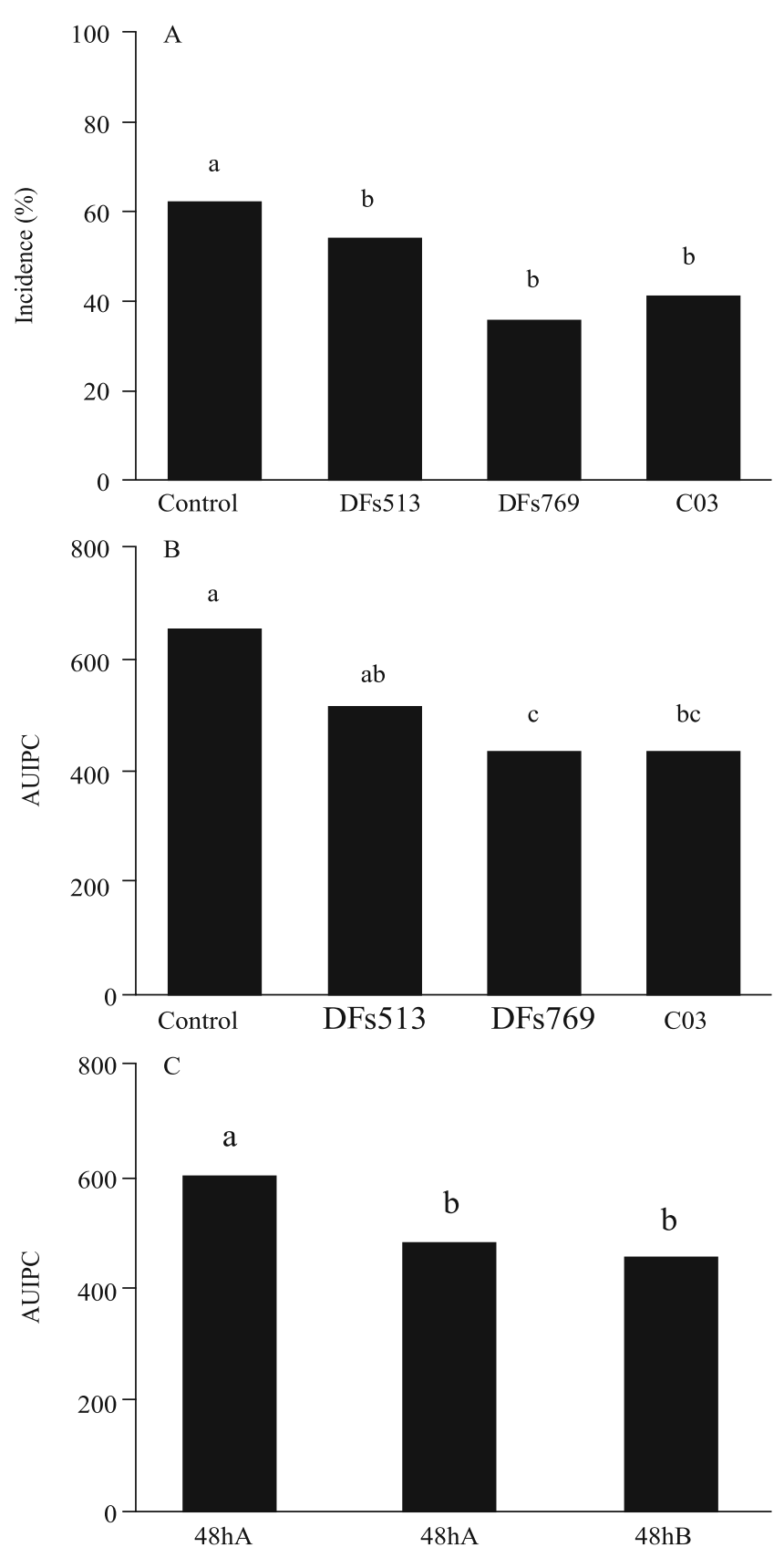

Figure 1. Incidence of common bacterial blight of bean (Xanthomonas axonopodis pv. phaseoli) due to the spraying of bacterial biocontrol agents on common bean (Phaseolus vulgaris) leaves 96 hours after pathogen inoculation(A), area under the incidence progress curve (AUIPC, B), and time of application (C). Control, water; DFs513, Pseudomonas veronii; DFs769, Bacillus cereus; C03, DFs348 (Bacillus sp.) + DFs769 + DFs831 (Pseudomonas fluorescens); 48hA, 48 hours after pathogen inoculation; $72 \mathrm{hB}, 72$ hours before pathogen inoculation; and $48 \mathrm{hB}, 48$ hours before pathogen inoculation. Means followed by equal letters do not differ by Duncan's test, at $5 \%$ probability. best treatments. In contrast to the results obtained in the present study, Corrêa (2017), working with 16 strains of Xap, concluded that the C01 combination resulted in maximum mean disease control. The authors found that the $\mathrm{C} 01$ combination and the DFs 831 bacterium caused the greatest reductions in CBB incidence and severity for all strains, resulting, respectively, in 36 and $27 \%$ control. Moreover, Corrêa et al. (2014) observed that the combination $\mathrm{C} 01$ had a broad spectrum of action, with an effective and significant control on all evaluated bean diseases: bacterial wilt, fusarium wilt, charcoal rot, and angular leaf spot. However, in both of these studies, BBAs were applied to the seed and not sprayed on leaves, which may be why the results differed from those obtained here regarding the control of CBB. Possibly, the bacterium DFs93, which is part of the C01 combination, has not adapted well in phylloplane, once it was isolated from the soil. This could explain its weak performance in controlling Xap in the present work, which is reinforced by the data for DFs93 when sprayed alone.

Combinations of microorganisms were explored by Mishra \& Arora (2012) to control Xanthomonas campestris pv. campestris (Xcc) through rhizosphere isolates, and the combination Pseudomonas and Bacillus resulted in greater control. According to these authors, the highest efficiency was due to complementary mechanisms of action: the Pseudomonas isolate produced siderophores and the Bacillus isolate produced autolysins and AHLlactonase. Siderophores are iron-chelating molecules, important in nutrient competition; autolysins hydrolyze the cell wall peptidoglycan, leading to bacterial lysis; and the AHL-lactonase action results in the hydrolysis of the signaling molecules acylhomoserine lactones, which causes the suppression of Xcc virulence genes.

Similar studies on the control of other bacterial diseases showed that combining application methods can be more efficient than using spray alone. In this sense, in a study on P. fluorescens applications for the control of Xanthomonas oryzae pv. oryzae in rice (Oryza sativa L.) plants, the best performance was observed when combining foliar, soil, and seed treatments (Jeyalakshmi et al., 2010). Mishra \& Arora (2012) evaluated two rhizobacteria isolates, Pseudomonas and Bacillus, for the biocontrol of $\mathrm{Xcc}$ in Brassica campestris L. and recorded a 
decrease between 32 and $57 \%$ in disease incidence, respectively; however, the highest reduction was achieved when seed microbiolization was combined with soil application.

Regarding pulverization time, greater reductions in disease severity were verified for preventive treatments, especially at 48 hours BPI (Table 1). These effective treatments reduced the symptoms of severity, on average, $25 \%$ in the first application and $50 \%$ in the second. However, treatments applied after inoculation with Xap, i.e., at 48 hours API, showed contradictory results in the two replicates of the assay. The curative effect of DFs513 was observed at the first time of application, and that of DFs769 and $\mathrm{C} 03$ at the second.

A greater preventive biocontrol may be attributed to at least three independent factors, which may occur simultaneously: competition, antibiosis, and induced resistance. Concerning the competition mechanism, the presence of BBAs in advance would increase the chance of bacterial multiplication and colonization. According to Halfeld-Vieira et al. (2015), the competition for iron and nitrogen compounds in leaves explains the control of $X$. axonopodis pv. passiflorae in passion fruit (Passiflora edulis Sims f. flavicarpa). Regarding antibiosis, if constitutively produced, BBAs would have been in leaves longer, allowing a greater accumulation of compounds toxic to the pathogen. The DFs93, DFs513, and DFs769 bacteria are producers of effective antimicrobial compounds against Xap (Silva et al., 2008), which is an indication of antibiosis, reported in several studies as a mechanism responsible for the biocontrol of plant pathogens (Lanna-Filho et al., 2010; Kumsingkaew \&
Akarapisan, 2014). For induced systemic resistance (ISR) to act as a mechanism, the presence of BBAs is required in advance to antagonize the pathogen. When applied in advance and spatially separated from the pathogen, DFs513, DFs769, and the C03 combination controlled CBB, acting by ISR.

Furthermore, a better preventive control involves the application not only of BBAs, but also of their metabolites. Spago et al. (2014) studied the effect of different compounds produced by $P$. aeruginosa against $X$. axonopodis pv. malvacearum (Xam), $X$. axonopodis pv. citri (Xac), and Xap, and found that certain fractions were more effective in controlling Xap and Xac, when applied preventively 24 hours before, and Xam, when applied curatively 24 hours after, reducing the number of leaf spots. The authors attributed the preventive effects to the induction of resistance, but did not rule out the possible involvement of antibiosis; this was also the case in the present study. Therefore, researches on the metabolites of DFs513 and DFs769, as well as on those of DFs93 and DFs831 that make up the $\mathrm{C} 03$ combination, should be carried out to confirm or exclude this possibility.

Regarding the systemic effect of BBAs via foliar spraying, there was no significant interaction between application time and BBAs in the first and second replicates, as well as no significant effect for the time of BBA pulverization in both replicates. In the first application, all BBA treatments showed systemic effect; the only exception was $\mathrm{C} 03$ for the AUSPC, which did not differ from the control (Table 2). In the second application, none of the BBAs reduced the AUIPC, and only the treatment with DFs769 showed

Table 1. Area under the severity progress curve (AUSPC) of the disease common bacterial blight of bean (Xanthomonas axonopodis pv. phaseoli) when common bean (Phaseolus vulgaris) leaves were sprayed with bacterial biocontrol agents before (BPI) or after pathogen inoculation (API) ${ }^{(1)}$.

\begin{tabular}{|c|c|c|c|c|c|c|c|}
\hline \multirow[t]{2}{*}{ Treatment } & \multicolumn{4}{|c|}{ Application time (first replicate) } & \multicolumn{3}{|c|}{ Application time (second replicate) } \\
\hline & 48 hours BPI & 24 hours BPI & 24 hours API & 48 hours API & 72 hours BPI & 48 hours BPI & 48 hours API \\
\hline Control & $33.93 \mathrm{aA}$ & $35.60 \mathrm{aA}$ & $30.68 \mathrm{bA}$ & $34.29 \mathrm{abA}$ & $23.97 \mathrm{aA}$ & $26.23 \mathrm{aA}$ & $26.71 \mathrm{aA}$ \\
\hline DFs $93^{(2)}$ & 29.18abAB & $31.68 \mathrm{aAB}$ & $34.64 \mathrm{abA}$ & $28.12 \mathrm{bcB}$ & - & - & - \\
\hline DFs $513^{(3)}$ & $26.95 \mathrm{bB}$ & $30.80 \mathrm{aAB}$ & 35.13abA & $27.32 \mathrm{cB}$ & $20.28 \mathrm{abB}$ & $14.96 \mathrm{bC}$ & $26.21 \mathrm{aA}$ \\
\hline DFs $769^{(4)}$ & $24.84 \mathrm{bB}$ & $30.23 \mathrm{aB}$ & $37.89 \mathrm{aA}$ & $36.56 \mathrm{aA}$ & $11.82 \mathrm{cB}$ & $11.63 \mathrm{bB}$ & $18.35 \mathrm{bA}$ \\
\hline $\mathrm{C} 1^{(5)}$ & 29.11abB & $32.00 \mathrm{aAB}$ & $31.05 \mathrm{bB}$ & $37.70 \mathrm{aA}$ & - & - & - \\
\hline $\mathrm{C} 03^{(6)}$ & $24.19 \mathrm{bB}$ & $32.02 \mathrm{aA}$ & 32.31abA & $35.17 \mathrm{aA}$ & $14.63 \mathrm{bcA}$ & $12.72 \mathrm{bA}$ & $15.97 \mathrm{bA}$ \\
\hline
\end{tabular}

${ }^{(1)}$ Means followed by equal letters, lowercase in the columns and uppercase in the lines for each application time, do not differ by Duncan's test, at $5 \%$ probability. ${ }^{(2)}$ Bacillus cereus. ${ }^{(3)}$ Pseudomonas veronii. ${ }^{(4)}$ Bacillus cereus. ${ }^{(5)} \mathrm{DFs} 93+\mathrm{DFs} 769+\mathrm{DFs} 831$ (Pseudomonas fluorescens). ${ }^{(6)} \mathrm{DFs} 348($ Bacillus sp.) + DFs769 + DFs831. 
a systemic effect for the AUSPC. The intensity of this control was similar to that of previous trials: a low and a more intense effect, respectively, on the incidence and on the severity of the disease. In this sense, in the first application, the AUIPC was reduced in $25 \%$, which was the average for all BBAs, and the AUSPC, in $42 \%$ for DFs513 and DFs769. The most intense effects were observed for the DFs769 treatment, which caused reductions of 37.6 and $45.7 \%$, respectively, in disease incidence and severity.

Among the beneficial microorganisms with potential to induce ISR, the bacteria of the genus Pseudomonas and Bacillus stand out. Planchamp et al. (2015) found that seed treatment with Pseudomonas putida KT2440 induced resistance in corn (Zea mays L.) plants against Colletotrichum graminicola. Kuhn \& Pascholati (2010) analyzed the protective effect of an isolate of $B$. cereus and of acibenzolar-S-methyl (ASM), as well the adaptive cost of resistance induction in beans against Xap. The authors reported that $B$. cereus and ASM caused a 37 and $79 \%$ reduction in CBB severity, respectively, but that the fungus has a significantly lower adaptive cost than the synthetic inducer. HalfeldVieira et al. (2006) also highlighted the potential of $B$. cereus to induce resistance, since, after it was sprayed, there was a lower severity of Pseudomonas syringae pv. tomato and a higher activity of peroxidase and systemic protection, which are indicative that the BBA acted as a promoter of ISR.

Table 2. Area under the incidence progress curve (AUIPC) and area under the severity progress curve (AUSPC) of the disease common bacterial blight of bean (Xanthomonas axonopodis pv. phaseoli) when common bean (Phaseolus vulgaris) leaves were sprayed with different bacterial biocontrol agents ${ }^{(1)}$.

\begin{tabular}{lllllr}
\hline \multirow{2}{*}{ Treatment } & \multicolumn{2}{c}{ First replicate } & & \multicolumn{2}{c}{ Second replicate } \\
\cline { 2 - 3 } \cline { 5 - 6 } & AUIPC & AUSPC & & AUIPC & AUSPC \\
\hline Control & $743.40 \mathrm{a}$ & $19.04 \mathrm{a}$ & & $665.36^{\text {ns }}$ & $16.71 \mathrm{a}$ \\
DFs513(2) & $598.96 \mathrm{~b}$ & $11.66 \mathrm{~b}$ & & 625.35 & $13.56 \mathrm{a}$ \\
$\mathrm{DFs}^{2} 79^{(3)}$ & $463.89 \mathrm{~b}$ & $10.34 \mathrm{~b}$ & & 520.86 & $9.23 \mathrm{~b}$ \\
$\mathrm{C03}^{(4)}$ & $603.12 \mathrm{~b}$ & $13.72 \mathrm{ab}$ & & 522.44 & $13.07 \mathrm{a}$ \\
\hline
\end{tabular}

(1)Means followed by equal letters, in the columns, do not differ by Duncan's test, at $5 \%$ probability. ${ }^{\text {ns }}$ Nonsignificant. ${ }^{(2)}$ Pseudomonas veronii. ${ }^{(3)}$ Bacillus cereus. ${ }^{(4)}$ DFs348 (Bacillus sp.) + DFs769 + DFs831 (Pseudomonas fluorescens).
Regarding phaseolin, a phytoalexin with recognized antifungal and antibacterial properties (Bozkurt \& Soylu, 2011), the pulverization of the DFs769 and DFs831 bacteria increased its production in bean hypocotyls by 31 and $47 \%$, respectively (Figure 2). The DFs769 and DFs831 (part of C03) bacteria also increased the production of phaseolin, indicating the potential of these BBAs to induce resistance, which may be related to lower CBB severity. Although there are no known studies on the induction of phaseolin by the application of B. cereus or P. fluorescens isolates, the accumulation of phaseolin in common bean has been reported after treatment with exogenous elicitors, such as rhizobacteria like $P$. putida (Ongena et al., 2004), plant extracts (Brand et al., 2010), and systemic acquired resistance inducers (Durango et al., 2013).

The results of the present study are indicative of the potential of BBAs, previously selected for seed treatment, for the control of CBB by foliar spraying, with flexibility in their use.

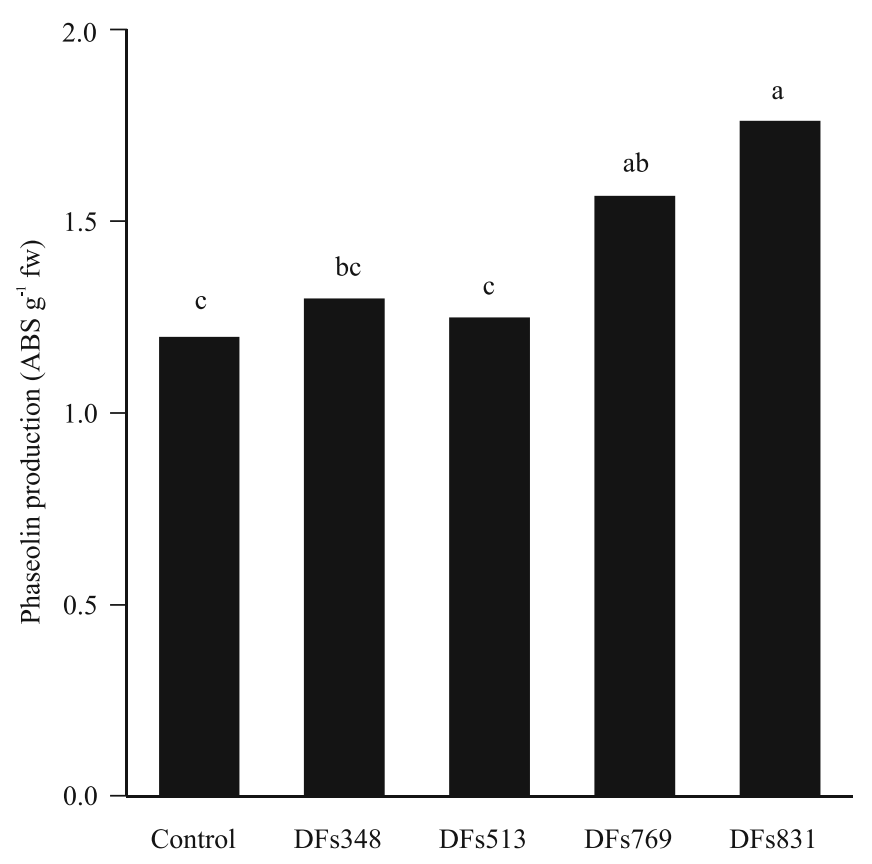

Figure 2. Production of phaseolin in common bean (Phaseolus vulgaris) hypocotyls treated with different bacterial biocontrol agents, expressed by absorbance (280 $\mathrm{nm})$ per gram of fresh weight. Means followed by equal letters, do not differ by Duncan's test, at $5 \%$ probability. Control, $0.85 \%$ saline solution; DFs348, Bacillus cereus; DFs513, Pseudomonas veronii; DFs769, B. cereus; and DFs831, Pseudomonas fluorescens. 


\section{Conclusions}

1. Foliar spraying of the bacterial biocontrol agents DFs513, DFs769, and the C03 combination (DFs348 + DFs769 + DFs831) controls common bacterial blight of bean (Phaseolus vulgaris).

2. The preventive foliar spraying with bacterial biocontrol agents is more effective than the curative one.

3. The bacterial biocontrol agents DFs513, DFs769, and the C03 combination act as inducers of Xanthomonas axonopodis pv. phaseoli resistance.

\section{References}

AKRAM, W.; ANJUM, T.; ALI, B. Searching ISR determinant/s from Bacillus subtilis IAGS174 against Fusarium wilt of tomato. Biocontrol, v.60, p.271-280, 2015. DOI: 10.1007/s10526-0149636-1.

ALFENAS, A.C.; MAFIA, R.G. (Ed.). Métodos em fitopatologia. Viçosa: Ed. da UFV, 2007. 382p.

BIANCHINI, A.; MARINGONI, A.C.; CARNEIRO, S.M.T.P.G. Doenças do feijoeiro. In: KIMATI, H.; AMORIM, L.; REZENDE, J.A.M.; BERGAMIN FILHO, A.; CAMARGO, L.E.A. (Ed.). Manual de fitopatologia: doenças das plantas cultivadas. 4.ed. São Paulo: Agronômica Ceres, 2005. v.2, p.333-349.

BOERSMA, J.G.; HOU, A.; GILLARD, C.L.; MCRAE, K.B.; CONNER, R.L. Impact of common bacterial blight on the yield, seed weight and seed discoloration of different market classes of dry beans (Phaseolus vulgaris L.). Canadian Journal of Plant Science, v.95, p.703-710, 2015. DOI: 10.4141/cjps-2014-399.

BOZKURT, I.A.; SOYLU, S. Determination of responses of different bean cultivars against races of Pseudomonas syringae pv. phaseolicola, causal agent of halo blight of bean. Euphytica, v.179, p.417-425, 2011. DOI: 10.1007/s10681-010-0339-0.

BRAND, S.C.; BLUME, E.; MUNIZ, M.F.B.; MILANESI, P.M.; SCHEREN, M.B.; ANTONELLO, L.M. Extratos de alho e alecrim na indução de faseolina em feijoeiro e fungitoxicidade sobre Colletotrichum lindemuthianum. Ciência Rural, v.40, p.1881-1887, 2010. DOI: 10.1590/S0103-84782010005000150.

CAMPBELL, C.L.; MADDEN, L.V. Introduction to plant disease epidemiology. New York: J. Wiley, 1990. 532p.

CORREAA, B.O.; SCHAFER, J.T.; MOURA, A.B. Spectrum of biocontrol bacteria to control leaf, root and vascular diseases of dry bean. Biological Control, v.72, p.71-75, 2014. DOI: 10.1016/j. biocontrol.2014.02.013.

CORRÊA, B.O.; SOARES, V.N.; SANGIOGO, M.; OLIVEIRA, J.R. de; MOURA, A.B. Interaction between bacterial biocontrolagents and strains of Xanthomonas axonopodis pv. phaseoli effects on biocontrol efficacy of common blight in beans. African Journal of Microbiology Research, v.11, p.1294-1302, 2017. DOI: 10.5897/AJMR2017.8565.
DIXON, R.A.; DEY, P.M.; LAWTON, M.A.; LAMB, C.J. Phytoalexin induction in French bean: intercellular transmission of elicitation in cell suspension cultures and hypocotyl sections of Phaseolus vulgaris. Plant Physiology, v.71, p.251-256, 1983. DOI: 10.1104/pp.71.2.251.

DURANGO, D.; PULGARIN, N.; ECHEVERRI, F.; ESCOBAR, G.; QUIÑONES, W. Effect of salicylic acid and structurally related compounds in the accumulation of phytoalexins in cotyledons of common bean (Phaseolus vulgaris L.) cultivars. Molecules, v.18, p.10609-10628, 2013. DOI: 10.3390/molecules180910609.

FIGUEREDO, M.S.; TONELLI, M.L.; TAURIAN, T.; ANGELINI, J.; IBAÑEZ, F.; VALETTI, L.; MUÑOZ, V.; ANZUAY, M.S.; LUDUEÑA, L.; FABRA, A. Interrelationships between Bacillus sp. CHEP5 and Bradyrhizobium sp. SEMIA6144 in the induced systemic resistance against Sclerotium rolfsii and symbiosis on peanut plants. Journal of Biosciences, v.39, p.877885, 2014. DOI: 10.1007/s12038-014-9470-8.

GILLARD, C.L.; CONNER, R.L.; HOWARD, R.J.; PAULS, K.P.; SHAW, L.; TARAN, B. The performance of dry bean cultivars with and without common bacterial blight resistance in field studies across Canada. Canadian Journal of Plant Science, v.89, p.405-410, 2009. DOI: 10.4141/CJPS08045.

HALFELD-VIEIRA, B. de A.; SILVA, W.L.M. da; SCHURT, D.A.; ISHIDA, A.K.N.; SOUZA, G.R. de; NECHET, K. de L. Understanding the mechanism of biological control of passionfruit bacterial blight promoted by autochthonous phylloplane bacteria. Biological Control, v.80, p.40-49, 2015. DOI: 10.1016/j. biocontrol.2014.09.011.

HALFELD-VIEIRA, B. de A.; VIEIRA JÚNIOR, J.R.; ROMEIRO, R. da S.; SILVA, H.S.A.; BARACAT-PEREIRA, M.C. Induction of systemic resistance in tomato by the autochthonous phylloplane resident Bacillus cereus. Pesquisa Agropecuária Brasileira, v.41, p.1247-1252, 2006. DOI: 10.1590/ S0100-204X2006000800006.

JACOBSEN, B.J.; ZIDACK, N.K.; LARSON, B.J. The role of Bacillus-based biological control agents in integrated pest management systems: plant diseases. Phytopathology, v.94, p.1272-1275, 2004. DOI: 10.1094/PHYTO.2004.94.11.1272.

JAMALIZADEH, M.; ETEBARIAN, H.R.; AMINIAN, H.; ALIZADEH, A. A review of mechanisms of action of biological control organisms against post-harvest fruit spoilage. EPPO Bulletin, v.41, p.65-71, 2011. DOI: 10.1111/j.13652338.2011.02438.x.

JEYALAKSHMI, C.; MADHIAZHAGAN, K.; RETTINASSABABADY, C. Effect of different methods of application of Pseudomonas fluorescens against bacterial leaf blight under direct sown rice. Journal of Biopesticides, v.3, p.487-488, 2010.

KADO, C.I.; HESKETT, M.G. Selective media for isolation of Agrobacterium, Corynebacterium, Erwinia, Pseudomonas, and Xanthomonas. Phytopathology, v.60, p.969-976, 1970. DOI: 10.1094/Phyto-60-969.

KHABBAZ, S.E.; ZHANG, L.; CÁCERES, L.A.; SUMARAH, M.; WANG, A.; ABBASI, P.A. Characterisation of antagonistic Bacillus and Pseudomonas strains for biocontrol potential

Pesq. agropec. bras., Brasília, v.53, n.10, p.1101-1108, Oct. 2018 DOI: $10.1590 / \mathrm{S} 0100-204 \mathrm{X} 2018001000003$ 
and suppression of damping-off and root rot diseases. Annals of Applied Biology, v.166, p.456-471, 2015. DOI: 10.1111/ aab.12196.

KUHN, O.J.; PASCHOLATI, S.F. Custo adaptativo da indução de resistência em feijoeiro mediada pela rizobactéria Bacillus cereus ou acibenzolar-S-metil: atividade de enzimas, síntese de fenóis e lignina e biomassa. Summa Phytopathologica, v.36, p.107-114, 2010. DOI: 10.1590/S0100-54052010000200001.

KUMSINGKAEW, S.; AKARAPISAN, A. Efficiency of Bacillus subtilis EPB14 as biocontrol to control bacterial leaf blight of anthurium. Journal of Agricultural Technology, v.10, p.755-766, 2014.

LANNA FILHO, R.; ROMEIRO, R. da S.; ALVES, E. Bacterial spot and early blight biocontrol by epiphytic bacteria in tomato plants. Pesquisa Agropecuária Brasileira, v.45, p.1381-1387, 2010. DOI: 10.1590/S0100-204X2010001200007.

MISHRA, S.; ARORA, N.K. Evaluation of rhizospheric Pseudomonas and Bacillus as biocontrol tool for Xanthomonas campestris pv. campestris. World Journal of Microbiology and Biotechnology, v.28, p.693-702, 2012. DOI: 10.1007/s11274-0110865-5.

MOURA, A.B.; CORRÊA, B.O.; DENARDIN, N.D’Á. Controle biológico de bactérias fitopatogênicas. Informe Agropecuário, v.251, p.65-72, 2009.

NAUE, C.R.; ROCHA, D.J.A.; MOURA, A.B. Biological control of tomato bacterial spot by seed microbiolization. Tropical Plant Pathology, v.39, p.413-416, 2014. DOI: 10.1590/S198256762014000500009 .

ONGENA, M.; DUBY, F.; ROSSIGNOL, F.; FAUCONNIER, M.L.; DOMMES, J.; THONART, P. Stimulation of the lipoxygenase pathway is associated with systemic resistance induced in bean by a nonpathogenic Pseudomonas strain. Molecular PlantMicrobe Interactions, v.17, p.1009-1018, 2004. DOI: 10.1094/ MPMI.2004.17.9.1009.
PLANCHAMP, C.; GLAUSER, G.; MAUCH-MANI, B. Root inoculation with Pseudomonas putida KT2440 induces transcriptional and metabolic changes and systemic resistance in maize plants. Frontiers in Plant Science, v.5, art.719, 2015. DOI: 10.3389/fpls.2014.00719.

R CORE TEAM. R: a language and environment for statistical computing. R Foundation for Statistical Computing: Vienna, 2015.

RAVA, C.A. Patogenecidade de isolamentos de Xanthomonas campestris pv. phaseoli. Pesquisa Agropecuária Brasileira, v.19, p.445-448, 1984

SILVA, E.G. da; MOURA, A.B.; BACARIN, M.A.; DEUNER, C.C. Alterações metabólicas em plantas de feijão originadas de sementes microbiolizadas por Pseudomonas sp. e inoculadas com Xanthomonas axonopodis pv. phaseoli. Summa Phytopathologica, v.35, p.98-104, 2009. DOI: 10.1590/S010054052009000200003.

SILVA, E.G. da; MOURA, A.B.; DEUNER, C.C.; FARIAS, D.R. Estudo de mecanismos de biocontrole do crestamento bacteriano do feijoeiro por bactérias. Revista Ceres, v.55, p.377-383, 2008.

SINGH, N.; SIDDIQUI, Z.A. Effects of Bacillus subtilis, Pseudomonas fluorescens and Aspergillus awamori on the wiltleaf spot disease complex of tomato. Phytoparasitica, v.43, p.6175, 2015. DOI: 10.1007/s12600-014-0427-0.

SPAGO, F.R.; ISHII MAURO, C.S.; OLIVEIRA, A.G.; BERANGER, J.P.O.; CELY, M.V.T.; STANGANELLI, M.M.; SIMIONATO, A.S.; SAN MARTIN, J.A.B.; ANDRADE, C.G.T.J.; MELLO, J.C.P.; ANDRADE, G. Pseudomonas aeruginosa produces secondary metabolites that have biological activity against plant pathogenic Xanthomonas species. Crop Protection, v.62, p.46-54, 2014. DOI: 10.1016/j.cropro.2014.04.011.

ZANATTA, Z.G.C.N.; MOURA, A.B.; MAIA, L.C.; SANTOS, A.S. dos. Bioassay for selection of biocontroller bacteria against bean common blight (Xanthomonas axonopodis pv. phaseoli). Brazilian Journal of Microbiology, v.38, p.511-515, 2007. DOI: 10.1590/S1517-83822007000300024.

Received on April 19, 2017 and accepted on December 20, 2017

Pesq. agropec. bras., Brasília, v.53, n.10, p.1101-1108, Oct. 2018

DOI: 10.1590/S0100-204X2018001000003 